\title{
PROTECTED AREAS IN BRAZIL: EVOLUTION, LAND USE AND COVER, AND IMPACT ON EMISSIONS INVENTORY
}

\author{
Roberta Zecchini Cantinho ${ }^{1 *}$, Jimmy Alexander Hernandez Linares² José Luiz Vieira $^{3}$, Mercedes Maria da \\ Cunha Bustamante ${ }^{2}$ \\ 1* Universidade de Brasília, Centro de Desenvolvimento Sustentável, Brasília, DF, Brasil - rzcantinho@gmail.com \\ ${ }^{2}$ Universidade de Brasília, Instituto de Ciências Biológicas, Departamento de Ecologia, Brasília, DF, Brasil - jimmyahl@ gmail.com \\ mercedes@unb.br \\ ${ }^{3}$ Associação Plantas do Nordeste, Recife, PE, Brasil - jlvieira@gmail.com
}

Received for publication: 01/07/2019 - Accepted for publication: 12/07/2020

\begin{abstract}
Resumo
Áreas protegidas no Brasil: evolução, uso e cobertura da terra e impacto no Inventário de Emissões. Diante do crescimento populacional e intensificação de uso dos recursos naturais, as Unidades de Conservação (PA) e as Terras Indígenas (IL) desempenham papel fundamental na conservação ambiental. Além disso, para fins de Inventário de Emissões, o incremento de carbono da vegetação protegida dentro dessas áreas é contabilizado como remoção de $\mathrm{CO}_{2}$ no setor de Uso da Terra, Mudança do Uso da Terra e Florestas (LULUCF). A avaliação topológica de sobreposições dos bancos de dados de PAs (de proteção integral e de uso sustentável) e ILs mostrou que estas chegam a representar $6 \%$ das áreas protegidas. Do total das áreas protegidas, $43 \%$ foram estabelecidas até $1994,26 \%$ até $2002,26 \%$ até 2010 e $4 \%$ entre 2011 e 2016 . Essa avaliação mostrou que $30 \%$ do território está dentro de PAs e ILs, sendo que, em termos de área, 84\% estão distribuídos no bioma Amazônia, 9\% no Cerrado, 4\% na Mata Atlântica, 3\% na Caatinga, 0,2\% no Pantanal e 0,3\% no Pampa. Ao avaliar o uso e cobertura de 2010 das áreas criadas até esse ano, notou-se que $68 \%$ da área total de PAs do País neste ano possuía vegetação preservada, ao passo que, com relação às áreas de ILs do País, esse percentual aumentou para $89 \%$. No âmbito do $3^{\circ}$ Inventário de Emissões, as remoções de $\mathrm{CO}_{2}$ pela vegetação preservada em PAs e ILs contribuíram para a diminuição em 16\% das emissões líquidas nacionais do setor LULUCF entre 2002 e 2010. Este dado demonstra a importância da preservação de florestas e campos.

Palavras-chave: unidades de conservação, terras indígenas, mudança do clima, gases de efeito estufa, LULUCF.
\end{abstract}

Abstract
Faced with population growth and intensification of the use of natural resources, Protected Areas (PA) and Indigenous Lands (IL) play a fundamental role in environmental conservation. The carbon increment of preserved vegetation within these areas is accounted for as $\mathrm{CO}_{2}$ removal in the Land Use, Land-Use Change, and Forestry (LULUCF) sector of the National Emissions Inventory. A topological evaluation of overlaps was made of the databases of PAs (full protection and sustainable use) and ILs, showing that they represent $6 \%$ of the protected areas. Of the total of PAs and ILs areas, $43 \%$ were established by 1994, 26\% by $2002,26 \%$ by 2010, and 4\% between 2011 and 2016. This evaluation showed that $30 \%$ of the territory is within PAs and ILs. In terms of area, $84 \%$ is distributed in the Amazon, $9 \%$ in the Cerrado, $4 \%$ in the Atlantic Forest, $3 \%$ in the Caatinga, 0,2\% in the Pantanal, and 0,3\% in the Pampa. In assessing the use and cover of 2010 of the PAs and ILs created up to this year, it was possible to notice that $68 \%$ of the areas within the PAs have preserved vegetation, whereas in ILs, this percentage increases to $89 \%$. Under the Third Emissions Inventory, the removal of vegetation protected in PAs and ILs decreased by $16 \%$ of the national net emissions of the LULUCF sector between 2002 and 2010, showing the importance of preserving forests and grasslands.

Keywords: conservation units, indigenous lands, climate change, greenhouse gases, LULUCF.

\section{INTRODUCTION}

Population growth is linked to an increased demand for natural resources to meet human needs. As a particular natural resource becomes scarce, the use of other products increases. This replacement dynamics generates a process of successive depletion of several natural resources (HASSLER, 2005).

Unchecked deforestation affects environmental conditions, such as humidity and heat. Therefore, the creation of protected areas is crucial to reestablish ecosystem services in disturbed landscapes (MAACK, 1981). The legal provisions that regulate the creation of protected areas (PAs) were established in the National System of Protected Areas (SNUC; BRAZIL, 2000). These PAs contribute to the protection of native biodiversity and to the restoration of degraded ecosystems, among other functions (ICMBIO, 2018).

In addition to the PAs, the Federal Union owns portions of the national territory inhabited by one or more indigenous peoples, which are designated as Indigenous Lands (ILs). These are used for the productive activities of indigenous peoples, and their demarcation is the responsibility of the National Indigenous Foundation (FUNAI). The National Policy for Territorial and Environmental Management of Indigenous Lands (PNGATI) ensures

FLORESTA, Curitiba, PR, v. 51, n. 1, p. 174-183, jan/mar 2021.

Cantinho, R. Z. et.al.

ISSN eletrônico 1982-4688

DOI: $10.5380 /$ rf.v51 i1. 67761 
protection, recovery, conservation and sustainable use of natural resources within ILs (BRASIL, 2012; CAVALCANTE VIEIRA, 2016).

Protected vegetation within PAs and ILs is also important for Brazil as a signatory to the United Nations Framework Convention on Climate Change (UNFCCC). One of its obligations as a developing country (nonAnnex-1) is to publish its "National Communication" every four years, which includes the "Brazilian Inventory of Anthropogenic Emissions and Removal of Greenhouse Gases not Controlled by the Montreal Protocol" (hereafter "Emissions Inventory"). Brazil's Initial Communication was published in 2004, when the country presented estimates of greenhouse gas (GHG) emissions from 1990 to 1994 (BRASIL, 2004). The Second National Communication, issued in 2010, updated emissions until 2005 (BRASIL, 2010) and was followed by the Third National Communication, issued in 2016, with emission estimates updated until 2010 (BRASIL, 2016a). The Fourth National Communication, which updated GHG emission estimates until 2016, was approved in 2020.

One of the sectors of the Emissions Inventory is "Land Use, Land-Use Change and Forestry" (LULUCF). The guidelines for the development of the Emissions Inventory are presented in the Intergovernmental Panel on Climate Change guides (IPCC, 2006). According to the IPCC, a managed area is one where human interventions and practices have been applied to perform productive, ecological or social functions (IPCC, 2006). Thus, for the purposes of the Emissions Inventory, Brazil includes in its accounting all vegetation (forest and grassland) protected within PAs and ILs in its various biomes, in addition to the actual anthropized areas (pasture, agriculture, etc.). Therefore, in terms of an increase in carbon stock, carbon removal by this vegetation is taken into account, resulting in a decrease of the country's net emissions. Therefore, it is important to avoid overlap of this information, as pointed out by Ricardo (2004), since it can lead to double counting of carbon removal in preserved forests and grasslands. Australia considers all forest, pasture and wetland areas as managed. New Zealand considers all pastures and forest areas as managed, while wetlands are considered unmanaged. Canada and the United States apply additional criteria to this distinction, subdividing forest areas and other uses into managed and unmanaged areas (OGLE et al., 2018).

In this context, it is important to analyze the evolution of the creation of PAs and ILs, as well as the conservation of national forests and grasslands within these protected areas, since biodiversity maintenance and the transformation of $\mathrm{CO}_{2}$ into carbon biomass through photosynthesis has an impact on $\mathrm{GHG}$ emissions at both national and global level. This initiative prioritized the use of official data; therefore, although other initiatives present more recent data, land use and cover were assessed until 2010, based on the Third National Communication (BRASIL, 2016a).

The objectives of this study were to assess the PAs and ILs created in the Country until 2016, and to analyze land use and cover in 2010 of the PAs and ILs created until 2010. Finally, the contribution of protected vegetation to Brazil's net GHG was measured.

\section{MATERIALS AND METHODS}

All analyzes were performed using a Geographic Information System (GIS). The software used were ArcGis and QGis. The methodological steps are presented in the flowchart of Figure 1.

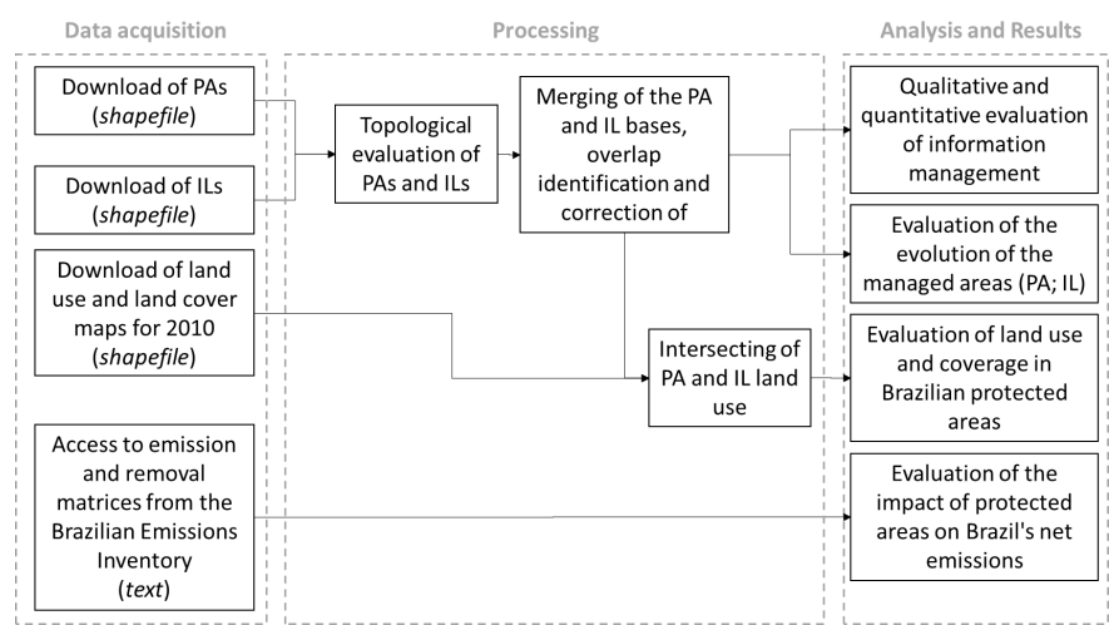

Key: ILs, Indigenous Lands; and PAs, Protected Areas.

Figure 1. Flowchart of methodological steps performed from data acquisition to analysis of the results.

Figura 1. Fluxograma de etapas metodológicas realizadas desde a aquisição de dados até a análise dos resultados.

Details of each methodological step will be provided below. 


\section{Data acquisition}

Spatialized files (in shapefile format) of PAs and ILs were acquired on July 19 and 31, 2018, respectively, from the databases of the Ministry of the Environment (MMA, 2018) and the National Indigenous Foundation (FUNAI, 2018). For this work, only the PAs and ILs created until 2016 are considered, as they reflect the database used in the scope of the IV Emissions Inventory, part of the Fourth National Communication. The Private Reserves of Natural Heritage (RPPNs) were not considered in this analysis; although they present amounts higher than those of all categories of PAs, they are not significantly representative in relation to the total area of PAs $(0.005 \%$, $0.0006 \%, 0.31 \%, 0.47 \%$ and $8.96 \%$ of the total area of PAs, in the case of the Pampa, Amazon, Cerrado, Atlantic Forest and Pantanal biomes, respectively). In addition, some of them overlap with other PAs. Despite expressive representation of the Pantanal biome, it was decided to maintain national consistency.

The indigenous land demarcation process (Article 231 of the 1988 Federal Constitution; Law 6,001; Decree 1,775/1996) is carried out in 5 stages, ranging from identification and delimitation of the area to registration as Federal Union property. This study focuses on the first stage and, when this information was not available, the following was considered.

The information on land use and cover for the year 2010 was acquired from the database of the $3^{\text {rd }}$ Emissions Inventory (BRASIL, 2016a). This map was generated by means of visual interpretation of medium resolution images (TM/Landsat and LISS3/ResouceSat-1) for the whole of Brazil, on a 1: 250,000 scale and minimum area of 6.25 ha. The maps database of the $3^{\text {rd }}$ Emissions Inventory also includes maps of the entire territory for the years 1994, 2002 and 2010, and specifically of the Amazon biome for 2005. As previously mentioned, it was decided to use only official data for this study, although there are other data sources, including more recent ones (MAPBIOMAS, 2019).

The matrices of gross vegetation emissions, vegetation removals, soil emissions and removals and net emissions, by period and biome, were obtained from the LULUCF Sector Reference Report of the $3^{\text {rd }}$ Emissions Inventory (BRASIL, 2016b).

Processing

Topological evaluation

The topological evaluation consisted of identifying doubling up of information in the same area, i.e., overlap between polygons in the shapefile.

Once the database had all the information needed for the evaluations, a topological evaluation of the PA and IL files was carried out. The ArcGis Topology tools were used to identify and quantify overlaps in the PA and IL shapefiles. In the topological analysis, performed in ArcGis, a cluster tolerance of 0.000000009 was maintained, which is automatically set by the software. When necessary, to simplify the analysis of the overlaps, the ArcGis dissolve tool was used to join the identified fragments.

Merging of PA and IT bases, overlap identification and correction

The QGis Intersection tool was used to identify possible overlaps between PAs and ILs, which have different sources of information. Next, the overlaps were adjusted, keeping the original information of the source files.

Intersection of protected areas and land use and cover

In order to evaluate land use and land cover in Brazilian protected areas, the IL and PA areas were intersected with the 2010 land use and land cover map generated in the scope of the $3^{\text {rd }}$ Emissions Inventory. The QGis Intersection tool was used for this purpose.

Evaluation of the impact of protected vegetation $\mathrm{CO}_{2}$ removal in PAs and ILs in LULUCF sector emissions

Based on the matrices of $\mathrm{CO}_{2}$ emission from land use and cover changes presented in the LULUCF sector reference report of the $3^{\text {rd }}$ Emissions Inventory, managed forest and grassland removals (FM and GM, respectively, according to the Emissions Inventory key) were specifically considered. For the purposes of the Brazilian inventory, "managed" forest or grassland means that this vegetation is protected within a PA or IL. The proportion of these removals in relation to the country's gross emissions was calculated in order to quantify the impact of accounting for these $\mathrm{CO}_{2}$ removals in Brazil's net emissions.

\section{RESULTS}

\section{Qualitative and quantitative evaluations on information management}

The results of the topological evaluations with respect to overlaps between protected areas, per biome, are presented in Table 1. 
Table 1. Evaluation of overlaps between protected areas (PAs and ILs) created until 2016 in Brazil. Tabela 1. Avaliação de sobreposições entre áreas protegidas (UCs e TIs) criadas até 2016 no Brasil.

\begin{tabular}{cccc}
\hline Overlaps & Biome & Number of overlapping areas & Total overlap area (ha) \\
\hline \multirow{4}{*}{ ILs vs. ILs } & Amazon & 4,494 & 540,423 \\
& Cerrado & 19 & 186,716 \\
& Atlantic Forest & 20 & 16,633 \\
& Caatinga & 4 & 1,566 \\
& Pampa & - & - \\
& Pantanal & 1 & 2,241 \\
& Amazon & 609,942 \\
& Cerrado & 108 & 765,178 \\
PAs vs. PAs & Atlantic Forest & 273 & 956,059 \\
& Caatinga & 5 & 23,999 \\
& Pampa & 1 & 2,606 \\
& Pantanal & - & - \\
& Amazon & 245 & $10,438,615$ \\
& Cerrado & 22 & 814,450 \\
& Atlantic Forest & 53 & 104,707 \\
& Caatinga & 11 & 1,016 \\
& Pampa & - & - \\
& Pantanal & 2 & 11 \\
& & 12,208 & $14,764,162$ \\
\hline
\end{tabular}

Key: PAs, Protected Areas; and ILs, Indigenous Lands.

Regarding the topological evaluation of national data on PAs provided by ICMBio, it was noted that overlaps occur mostly when considering different government spheres (municipal, state and federal). Overlaps were also found in the official data on ILs provided by FUNAI. When merging the PA and IL bases, the overlap between ICMBio and FUNAI data was also significant.

The overlaps in the Amazon biome amounted to 11,888,980 ha, which represents $6 \%$ of the biome's total protected area. The Cerrado and Atlantic Forest presented overlaps of 1,766,343 ha and 1,077,399 ha, respectively, equivalent to $8 \%$ and $11 \%$ of the total protected areas in each of these biomes. For Caatinga and Pampa, the overlapping areas represented $0.4 \%$ and $1 \%$ of the total protected areas of these biomes $(25,081$ ha and 2,605 ha). As for the Pantanal, an overlap area between ILs was adjusted according to a re-study of the area and only one overlap between PAs and ILs was found, which represents $0.3 \%$ biome (2,252 ha).

These overlaps represent $6 \%$ of all protected areas in the country by 2016 . The biomes where these overlaps were most significant are the Amazon and the Cerrado.

At the national level, the overlap areas that were found represent $6 \%$ of all areas of PAs and ILs in the country, considering all those created up to 2016.

Evaluation of the evolution of protected areas until 2016

In the case of the Amazon biome, 274 PAs and 331 ILs were identified. It was not possible to find information on the date of creation of $15 \mathrm{ILs}$, whose total area represented 1,091,233.21 ha. In the Cerrado, 217 PAs and $101 \mathrm{ILs}$ were verified, of which $11 \mathrm{ILs}$ had no creation date and were disregarded (197,506 ha). As for the Atlantic Forest biome, 556 PAs and 145 ILs were identified. Of these, 7 ILs with no date (amounting to 1,477 ha) were disregarded in the analyzes. For the Caatinga biome, 99 PAs and 39 ILs were identified, while 9 indigenous lands $(83,475$ ha) with no year of creation were disregarded. In the Pampa biome, 17 PAs and 8 ILs were identified, two of which had no creation date (138.4 ha). 7 PAs and 8 ILs were registered in the Pantanal biome. Of the total protected area in the country, $84 \%$ is found in the Amazon biome, $9 \%$ in the Cerrado, $4 \%$ in the Atlantic Forest, 3\% in the Caatinga, $0.2 \%$ in the Pantanal and $0.3 \%$ in the Pampa.

Table 2 presents the evolution of protected areas in Brazil considering the years 1994, 2002, 2010 and 2016 as evaluation points. These points were considered according to the years mapped in the Emissions Inventories of Brazil. The distribution of these PAs and ILs in the country in 2016 can be seen in Figure 2. 
Table 2. Total protected areas (Protected Areas and Indigenous Lands) in 1994, 2002, 2010 and 2016, in hectares, in Brazil.

Tabela 2. Total de áreas protegidas (Unidades de Conservação e Terras Indígenas) em 1994, 2002, 2010 e 2016 , em hectares, no Brasil.

\begin{tabular}{|c|c|c|c|c|c|c|}
\hline Biome & Year & Until 1994 & Until 2002 & Until 2010 & Until 2016 & $\begin{array}{c}\% \text { of } \\
\text { protected } \\
\text { area in } \\
2016\end{array}$ \\
\hline \multirow{2}{*}{ Amazon } & Areas created in the period (ha) & $92,957,353$ & $48,303,195$ & $59,988,691$ & $9,850,380$ & \multirow{2}{*}{$50 \%$} \\
\hline & Total area in the year (ha) & $92,957,353$ & $141,260,548$ & $201,249,239$ & $211,099,619$ & \\
\hline \multirow{2}{*}{ Cerrado } & Areas created in the period (ha) & $9,538,247$ & $10,657,543$ & $2,467,464$ & 434,228 & \multirow{2}{*}{$11 \%$} \\
\hline & Total area in the year (ha) & $9,538,247$ & $20,195,790$ & $22,663,254$ & $23,097,482$ & \\
\hline \multirow{2}{*}{$\begin{array}{l}\text { Atlantic } \\
\text { Forest }\end{array}$} & Areas created in the period (ha) & $5,091,228$ & $2,634,611$ & $1,299,184$ & 643,185 & \multirow{2}{*}{$9 \%$} \\
\hline & Total area in the year (ha) & $5,091,228$ & $7,725,839$ & $9,025,022$ & $9,668,208$ & \\
\hline \multirow{2}{*}{ Caatinga } & Areas created in the period (ha) & 710,423 & $4,188,789$ & $1,486,332$ & 176,503 & \multirow{2}{*}{$8 \%$} \\
\hline & Total area in the year (ha) & 710,423 & $4,899,211$ & $6,385,543$ & $6,562,046$ & \\
\hline \multirow{2}{*}{ Pampa } & Areas created in the period (ha) & 396,501 & 107,506 & 466 & 1,334 & \multirow{2}{*}{$3 \%$} \\
\hline & Total area in the year (ha) & 396,501 & 504,007 & 504,473 & 505,807 & \\
\hline \multirow{2}{*}{ Pantanal } & Areas created in the period (ha) & 318,907 & 207,522 & 171,018 & - & \multirow{2}{*}{$5 \%$} \\
\hline & Total area in the year (ha) & 318,907 & 526,429 & 697,447 & 697,447 & \\
\hline \multirow{2}{*}{ Brazil } & Areas created in the period (ha) & $109,012,659$ & $66,099,165$ & $65,413,154$ & $11,105,629$ & \multirow{2}{*}{$30 \%$} \\
\hline & Total area in the year (ha) & $109,012,659$ & $175,111,824$ & $240,524,978$ & $251,630,607$ & \\
\hline
\end{tabular}

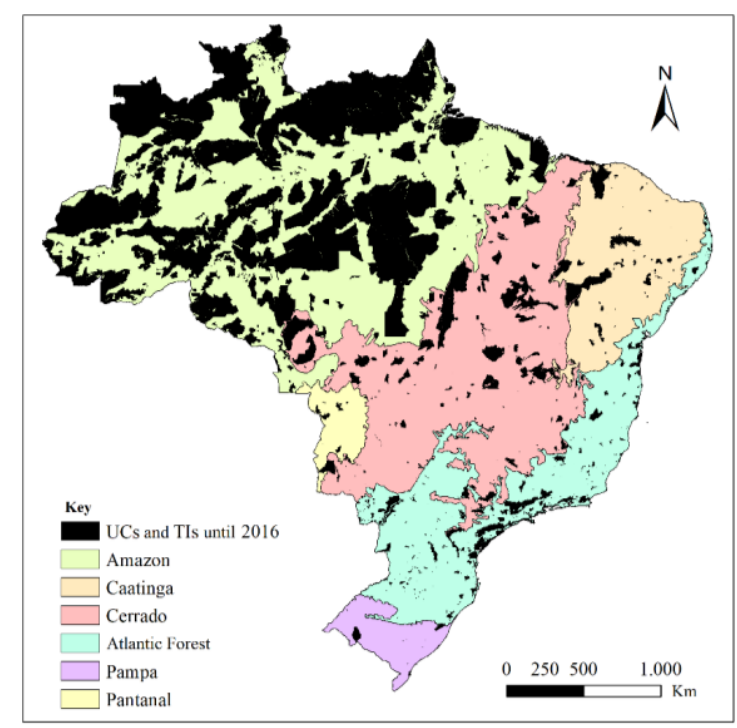

Figure 2. Distribution of the areas of Protected Areas and Indigenous Lands in Brazil, in 2016.

Figura 2. Distribuição das áreas de Unidades de Conservação e Terras Indígenas do Brasil, em 2016.

One can see that $43 \%$ of protected areas were established until 1994. By 2002, an additional $26 \%$ were created, and another $26 \%$ were added until 2010. Between 2011 and 2016, only $4 \%$ of the total areas were created. In the case of the Amazon biome, 44\% of the areas were established until 1994, 23\% until 2002, 28\% until 2010 and 5\% until 2016. In the Cerrado, $41 \%$ of the areas were created until 1994; $46 \%$ until 2002 and $11 \%$ and $2 \%$ of the areas were added until 2010 and 2016, respectively. In the case of the Atlantic Forest, 53\% of the PAs and ILs were established until 1994, while 27\%, 13\% and 7\% were created until 2002, 2010 and 2016, respectively. In the Caatinga, only $11 \%$ of the protected areas had been established by 1994; the peak of PA and IL establishment for this biome occurred between 1995 and 2002 (64\% of protected areas) and the remaining 23\% and 3\% were established between 2010 and 2016, respectively. For the Pampa biome, $78 \%$ of protected areas were established until 1994 and another $21 \%$ were added until 2002. In the case of the Pantanal, almost half of the protected areas were established until 1994, followed by $30 \%$ until 2002 and $25 \%$ until 2010 . Thus, it is observed that the creation of new IL or PA areas has decreased, while the occupation of the territory with anthropic use, such as pasture and 
agriculture, is increasing (BRASIL, 2016b). It is noted that, of the approximately $30 \%$ of the territory contained in PAs or ILs until 2016, the biome with the largest share within protected areas is the Amazon, followed by the Cerrado, the Atlantic Forest, the Caatinga, the Pantanal and the Pampa, respectively. The biomes with the largest protected area are also the ones with the highest representativeness of vegetation with forest structure (MTIC, 2016).

Land use and cover in Brazil's protected areas

The results are presented in relation to the percentage of representativeness of each use in 2010, being: i) protected vegetation (referring to water, managed forest and grassland classes in the $3^{\text {rd }}$ Emissions Inventory); ii) secondary vegetation; iii) agriculture and reforestation; iv) pasture and v) other land (areas not observed due to clouds and shadows, urban area, mining, dunes and artificial reservoirs). For this stage of the evaluation, only the PAs and ILs created until 2010 were considered. Figure 3 shows land use and land cover distribution within PAs in the country in 2010, by biome, while Figure 4 presents the results for ILs.

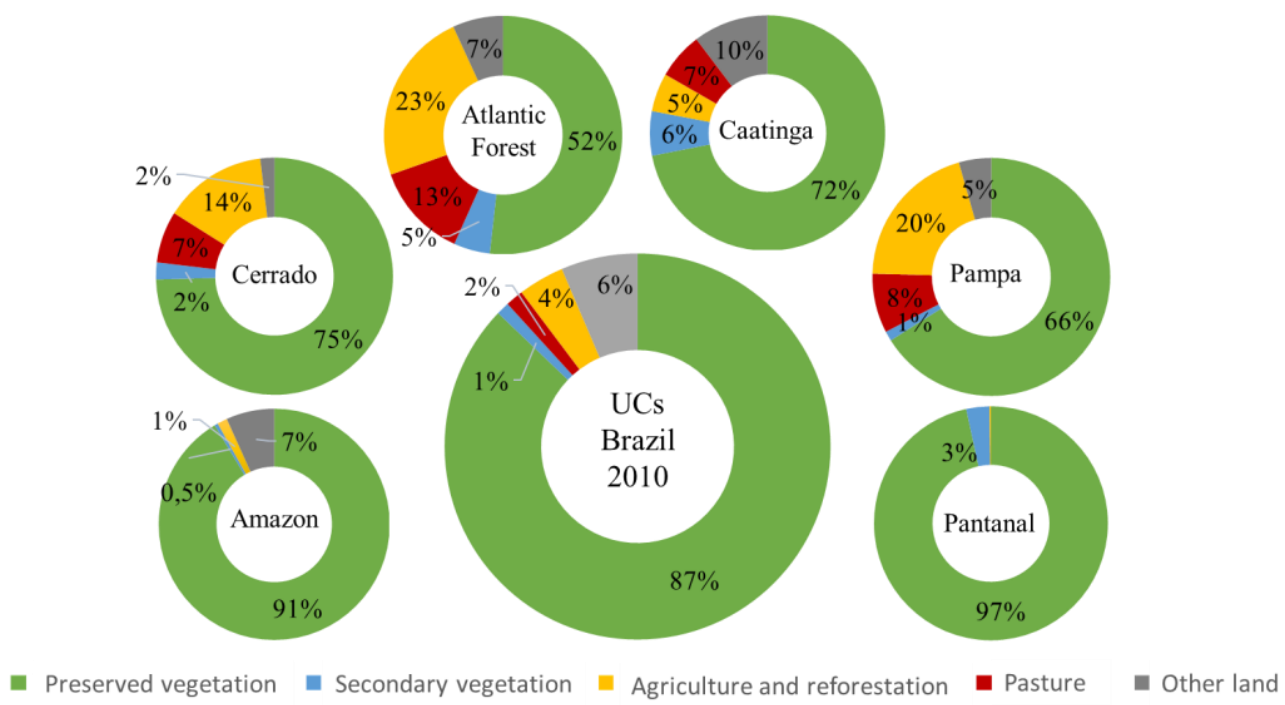

Source: ICMBIO (2018); BRAZIL (2016b).

Figure 3. Distribution of the use and cover of Protected Areas in 2010, by biome.

Figura 3. Distribuição do uso e cobertura das Unidades de Conservação, em 2010, por bioma.

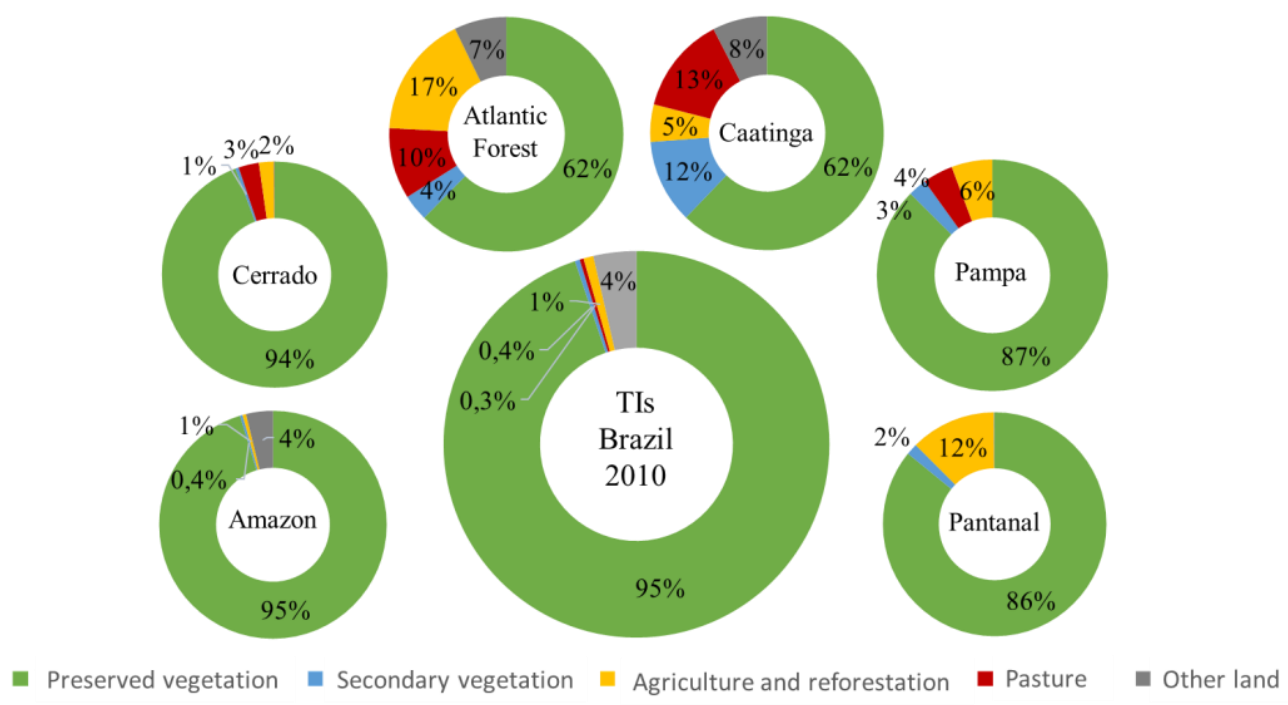

Source: ICMBIO (2018); BRAZIL (2016b).

Figure 4. Distribution of the use and cover of Indigenous Lands of Brazil, in 2010, by biome.

Figura 4. Distribuição do uso e cobertura das Terras Indígenas do Brasil, em 2010, por bioma.

Impacts of $\mathrm{CO}_{2}$ removals from protected vegetation in PAs and ILs in LULUCF sector emissions

FLORESTA, Curitiba, PR, v. 51, n. 1, p. 174-183, jan/mar 2021.

Cantinho, R. Z. et.al.

ISSN eletrônico 1982-4688

DOI: $10.5380 /$ rf.v51 i1. 67761 
Brazil's Emissions Inventory takes into account forests and grasslands preserved within PAs and ILs as "managed", since there is some anthropic intervention on that land, according to the IPCCs concept of "managed". In this case, specifically, it is assumed that this vegetation is preserved thanks to the designation of the land as protected. For the sake of clarity, this concept is not linked to a "Management Plan", for example.

Based on the carbon dioxide $\left(\mathrm{CO}_{2}\right)$ removal matrices of the $3^{\text {rd }}$ Emissions Inventory for the 2002 to 2010 period, the following cases were considered:

1) Protected forest within PAs or ILs: represented in the Emissions Inventory as Managed Forest remaining Managed Forest (FM-FM) from 2002 to 2010;

2) Preserved grassland within PAs or ILs: represented in the Emissions Inventory as Managed Grassland remaining Managed Grassland (GM-GM) in the period from 2002 to 2010;

3) Protected forest in PAs or ILs created over the 2002 to 2010 period: conversion represented in the Emissions Inventory as Unmanaged Forest to Managed Forest (FNM-FM);

4) Preserved grassland in PAs or ILs created over the 2002 to 2010 period: conversion represented in the Emissions Inventory as Unmanaged Grassland to Managed Grassland (GNM-GM).

The annual increase factors for carbon in primary forests used in the $3^{\text {rd }}$ Emission Inventory are $0.43 \mathrm{tC} / \mathrm{ha}$ for the Amazon, $0.2 \mathrm{tC} / \mathrm{ha}$ for the Cerrado and Pantanal, $0.1 \mathrm{tC} / \mathrm{ha}$ for the Caatinga and $0.32 \mathrm{tC} / \mathrm{ha}$ for the Atlantic Forest. For primary grasslands, the value used was $0.52 \mathrm{tC} / \mathrm{ha}$ per year for all biomes (BRASIL, 2016b). In addition, for situations 3 and 4 described above, removals are accounted for during half of the period, i.e., instead of considering removals for the full period (8 years from 2002 to 2010), removals for half the period are considered (4 years). This carbon gain is converted to $\mathrm{CO}_{2}$ by means of the conversion factor (multiplying by 44/12) and, because there is an increase in biomass and, consequently, in carbon removal from the atmosphere, they are subtracted from the total emissions resulting mainly from forest conversions to deforestation.

Table 3 presents removals from forests and primary grasslands within PAs and ILs from 2002 to 2010. These values are presented in gigagrams (or 1,000 tons) of carbon dioxide $\left(\mathrm{CO}_{2}\right)$, the unit used to present results in the emission inventories. In this study, carbon removals resulting from the growth of secondary vegetation or even land use conversions linked to some gain in carbon stock were not considered (for example, pasture converted to reforestation represents a carbon gain and, consequently, $\mathrm{CO}_{2}$ sequestration). The gross emission values are also presented, i.e., without considering any carbon gain, by biome, in the period, and the impact that removals have on these emissions.

Table 3. Carbon removals (in $\mathrm{Gg} \mathrm{CO}_{2}$ ) from forests and preserved grasslands within PAs and ILs between 2002 and 2010 in Brazil.

Tabela 3. Remoções de carbono (em $\mathrm{Gg} \mathrm{CO}_{2}$ ) de florestas e campos preservados dentro de áreas UCs e TIs entre 2002 e 2010 no Brasil.

\begin{tabular}{|c|c|c|c|c|c|c|c|}
\hline & Amazon & Cerrado & $\begin{array}{l}\text { Atlantic } \\
\text { Forest }\end{array}$ & Caatinga & Pampa & Pantanal & Brazil \\
\hline $\begin{array}{l}\text { FM-FM removals } \\
\quad\left(\mathrm{Gg} \mathrm{CO}_{2}\right)\end{array}$ & $1,654,659$ & 63,975 & 42,587 & 10,411 & 338 & 1,907 & $1,773,878$ \\
\hline $\begin{array}{c}\text { FMNM-FM } \\
\text { removals }\left(\mathrm{Gg} \mathrm{CO}_{2}\right)\end{array}$ & 183,726 & 3,391 & 2,076 & 1,344 & - & 346 & 190,884 \\
\hline $\begin{array}{l}\text { GM-GM removals } \\
\qquad\left(\mathrm{Gg} \mathrm{CO}_{2}\right)\end{array}$ & 59,802 & 102,397 & 2,876 & 2,079 & 4,429 & 2,081 & 173,663 \\
\hline $\begin{array}{l}\text { GM-GNM removals } \\
\qquad\left(\mathrm{Gg} \mathrm{CO}_{2}\right)\end{array}$ & 3,937 & 6,820 & 372 & 175 & 2 & 37 & 11,343 \\
\hline $\begin{array}{l}\text { Removals from } \\
\text { protected vegetation } \\
\text { in PAs and ILs }(\mathrm{Gg} \\
\left.\mathrm{CO}_{2}\right)\end{array}$ & $1,902,124$ & 176,583 & 47,911 & 14,010 & 4,769 & 4,371 & $2,149,768$ \\
\hline $\begin{array}{l}\text { Net emissions } \\
\text { (without removal } \\
\text { from protected } \\
\text { vegetation; } \mathrm{Gg} \mathrm{CO}_{2} \text { ) }\end{array}$ & $8,759,149$ & $2,021,608$ & $2,008,894$ & 91,718 & 111,592 & 138,284 & $13,131,245$ \\
\hline $\begin{array}{l}\text { Removals/ Net } \\
\text { emissions (\%) }\end{array}$ & $22 \%$ & $9 \%$ & $2 \%$ & $15 \%$ & $4 \%$ & $3 \%$ & $16 \%$ \\
\hline
\end{tabular}

Key: PAs, Protected Areas; ILs, Indigenous Lands; FM-FM, protected forest within PAs or ILs between 2002 and 2010; GM-GM, preserved grassland within PAs or ILs between 2002 and 2010; FNM-FM, protected forest in PAs or ILs created over the 2002 to 2010 period; GNMGM, preserved grassland in PAs or ILs created over the 2002 to 2010 period.

Source: modified from BRASIL (2016b).

The results are discussed below. 


\section{DISCUSSION}

The overlaps found both in the institutions' own data (in this case, ICMBio and FUNAI), as well as in the process of gathering information, indicated the need to adjust not only the bases themselves, geometrically speaking, but also aligning the hierarchy of the different government spheres and entities. These overlaps were also discussed and presented by Ricardo (2004). As mentioned earlier, overlaps can generate a doubling up of $\mathrm{CO}_{2}$ removal count linked to preserved forests and grasslands in protected areas. The adjustment of the official database represents a meticulous processing step within the scope of the Emissions Inventory, since this base cannot simply be incorporated into the processing in the format provided by the bodies responsible for generating this information. In addition, as $\mathrm{CO}_{2}$ removals are counted from the date of creation of the PA or IL, it is always necessary to allocate a year to that overlap area. Therefore, this association is made subjectively, since, for most cases, the years of creation are not coincident and there is no consensus on the hierarchy in relation to the creation of areas, as also discussed by Ferreira (2018). These overlaps also occur in PAs and ILs that do not allow the same level of intervention in the areas, which also hinders the enforcement of legislation on protected areas.

Regarding the evaluation of land use and cover within PAs for 2010, Sustainable Use (SU) and Full Protection (FP) PAs are being considered. The SU PAs do not, therefore, reflect the main objective of the FP PAs, which is to preserve vegetation. In the case of the Pantanal, due to the characteristics of the biome, there are limitations/restrictions to exploitation of the vegetation which contribute to its preservation. In the case of the Pampa, many pasture areas (20\%) possibly represent grassland areas used for grazing, but that would not necessarily be connected to a conversion of use. The same seems to occur in the Cerrado biome. In the case of the Atlantic Forest, practically $50 \%$ of the areas would in fact be protected, with a significant share of the PAs being used for agricultural crops and reforestation. In the case of the Caatinga, $10 \%$ of the "Other land" class is represented by areas not observed in the map prepared for the $3^{\text {rd }}$ Emissions Inventory. The same is true for the Amazon biome, where the unobserved areas of 2010 represent $6 \%$ of the $7 \%$ of the "Other land" class". The difficulty in these cases is to associate these areas with preservation or anthropic use. The results presented by Mattar et al. (2018) show vegetation conservation scenarios greater than those presented in this study, as they only consider federal PAs. The authors do not make it clear whether only FP PAs were considered, but they also do not consider RPPNs. In the case of the Emissions Inventory, the different types of management established in protected areas (i.e., full protection, sustainable use) are not considered, but the entire dynamics of land use and cover is considered. The Emissions Inventory considers the carbon increase from preserved vegetation in the protected areas, which is the only difference in relation to the rest of the territory, i.e., outside the PAs and ILs.

The land use and land cover evaluation within ILs for 2010 showed that most of these areas are preserved. With respect to the Pantanal and Pampa, possibly, areas of natural grassland used for grazing were included in the pasture class. The areas within the IL of the Cerrado and Amazon biomes are practically all preserved. Regarding the Atlantic Forest and Caatinga biomes, practically $60 \%$ of the areas would in fact be preserved, with a significant share being used for pasture, agricultural crops and reforestation. In this sense, it is worth questioning whether the PNGATI monitoring is taking place efficiently in these regions. The legislation applied to ILs is being reviewed to allow more intensive use of the areas, so it is essential to ascertain the position of the communities in relation to the current legislation and possible changes, in order to balance their need for production with the need for preservation. Even though the areas within the ILs are preserved, it is important to evaluate their surroundings in terms of the regional and economic context (BRONDIZIO et al., 2009).

The preservation of vegetation plays an important role in accounting for Brazil's net emissions. Nogueira et al. (2018) correlate protected areas and their carbon stock, in order to quantify the associated carbon losses. Likewise, the authors highlight the importance of preserving vegetation in these areas. Soares-Filho et al. (2010) also evaluated land use and cover in protected areas, highlighting the need for preservation not only in these areas, but also the importance of private landowners in the scope of the Forest Code. From the point of view of the Emissions Inventory, however, it is still necessary to question whether considering removals from preserved forests and grasslands in the long term will not lead to a false impression that the country has effectively protected its vegetation.

\section{CONCLUSIONS}

- It is essential to ensure interaction and harmonization of data from government agencies responsible for data on PAs (ICMBio) and ILs (FUNAI), since these data should complement one another and not overlap. The management of the use of protected areas is directly impacted by the instrument that governs them. For the Emissions Inventory, overlaps may represent double counting of removals by carbon increment from preserved forests and grasslands in these areas.

- The use and cover of the PA land showed that a large share involves Sustainable Use (SU), while indigenous lands have played a key role in preserving vegetation. The distinction between FP PAs and SU PAs is very

FLORESTA, Curitiba, PR, v. 51, n. 1, p. 174-183, jan/mar 2021.

Cantinho, R. Z. et.al.

ISSN eletrônico 1982-4688

DOI: $10.5380 /$ rf.v51 i1. 67761 
important, since they have different objectives, as well as different rules and levels of restrictions regarding land use and occupation. Therefore, this distinction should be considered in future analyzes.

- The protection of forests and grasslands within PAs and ILs has a significant impact on Brazil's GHG emissions inventory, and it is important to assess whether the inventory methodology employed to account for removals throughout the inventory period is in fact consistent with the reality of forests that have already reached the climax stage.

- This research has limitations in terms of time cutoff because official data on land use and land cover across the country has not yet been updated. Evaluations could be carried out in a subsequent step by separating SU PAs from FP PAs. Although this limitation exists, this work represents a key contribution to the discussion on the accounting and monitoring of national GHG emissions, with a focus on improving analysis methods and criteria.

- This study is aligned with Sustainable Development Objective (SDG) number 13, which concerns action against global climate change, part of the 2030 UN Agenda for Sustainable Development.

\section{ACKNOWLEDGEMENTS}

We thank the Global Environment Fund (GEF) and the United Nations Development Program (UNDP) for the resources that made it possible to carry out this research in the scope of the $4^{\text {th }}$ National Communication. We also thank the Ministry of Science, Technology and Innovations (MCTI) for allowing access to the organized database to be used in the $4^{\text {th }}$ Brazilian Emissions Inventory of the Land Use, Land-Use Change and Forests sector and the support of the Climate Network (Rede Clima) in technical discussions. We extend our thanks to the representatives of ICMBio and FUNAI for their guidance on data acquisition.

\section{REFERENCES}

ARCGIS: Software. Disponível em <http://www.esri.com/software/arcgis/index.html>. Acesso em: 05 fev. 2018.

BRASIL. Lei Federal No 9.985, de 18/07/2000. Regulamenta o art. 225, § 1o, incisos I, II, III e VII da Constituição Federal, institui o Sistema Nacional de Unidades de Conservação da Natureza e dá outras providências. Diário Oficial da União, Brasília, DF, 18 de julho de 2000. Disponível em: http://www.planalto.gov.br/ccivil_03/leis/19985.htm. Acesso em: 03 mar. 2019.

BRASIL. Ministério da Ciência e Tecnologia. Secretaria de Políticas e Programas de Pesquisa e Desenvolvimento. Coordenação-Geral de Mudanças Globais de Clima. Parte 2: Inventário de Emissões e Remoções Antrópicas de Gases de Efeito Estufa não Controlados pelo Protocolo de Montreal. 2004.

BRASIL. Ministério da Ciência e Tecnologia. Secretaria de Políticas e Programas de Pesquisa e Desenvolvimento. Coordenação-Geral de Mudanças Globais do Clima. Segunda Comunicação Nacional do Brasil à ConvençãoQuadro das Nações Unidas sobre Mudança do Clima. 2010.

BRASIL. Ministério da Ciência, Tecnologia e Inovação. Secretaria de Políticas e Programas de Pesquisa e Desenvolvimento. Coordenação-Geral de Mudanças Globais de Clima. Terceira Comunicação Nacional do Brasil à Convenção-Quadro das Nações Unidas sobre Mudança do Clima - Volume III/ Ministério da Ciência, Tecnologia e Inovação. Brasília: Ministério da Ciência, Tecnologia e Inovação, $2016 a$.

BRASIL. Ministério da Ciência, Tecnologia e Inovação. Secretaria de Políticas e Programas de Pesquisa e Desenvolvimento. Coordenação-Geral de Mudanças Globais de Clima. Terceiro Inventário Brasileiro de Emissões e Remoções Antrópicas de Gases de Efeito Estufa. Relatórios de Referência - Setor uso da terra, mudança do uso da terra e florestas. 343 p. $2016 \mathrm{~b}$.

BRASIL. Decreto No 7.747, de 05/06/2012. Institui a Política Nacional de Gestão Territorial e Ambiental de Terras Indígenas - PNGATI, e dá outras providências. Diário Oficial da União, Brasília, DF, 05 de junho de 2012. Disponível em http://www.planalto.gov.br/ccivil_03/_ato2011-2014/2012/decreto/d7747.htm. Acesso em: 04 abr. 2019.

BRONDIZIO, E. S.; OSTROM, E.; YOUNG, O. R. Connectivity and the Governance of Multilevel SocialEcological Systems: The Role of Social Capital. Annual Review of Environment and Resources. V. 34: p. 25378. 2009.

FERREIRA. When the blanket is too short: Potential negative impacts of expanding indigenous land over a national park in a high priority area for conservation. Land Use Policy. v. 76, p. 359-364. 2018.

SOARES-FILHO, B. et al. Role of Brazilian Amazon protected areas in climate change mitigation. Proceedings

FLORESTA, Curitiba, PR, v. 51, n. 1, p. 174-183, jan/mar 2021.

Cantinho, R. Z. et.al.

ISSN eletrônico 1982-4688

DOI: $10.5380 /$ rf.v51 i1. 67761 
of the National Academy of Sciences, v. 107, n. 24, p. 10821-10826, 2010.

CAVALCANTE VIEIRA, Thiago Leandro. Terra Indígena: Aspectos Históricos da Construção e Aplicação de um Conceito Jurídico. História, V.35, e75. São Paulo. 2016

FUNAI. Fundação Nacional do Índio. Disponível em <http://www.funai.gov.br/index.php/i3geo>. Acesso: em 31 jul. 2018

HASSLER, M. L. A importância das Unidades de Conservação no Brasil. Sociedade \& Natureza, Uberlândia, 17(33): 79-89, dez. 2005.

ICMBIO. Instituto Chico Mendes de Conservação da Biodiversidade. Disponível em <http://www.icmbio.gov.br/portal/criesuareserva>. Acesso em: 02 ago. 2018

IPCC. Guidelines for National Greenhouse Gas Inventories. Volume 4: Agriculture, Forestry, and Other Land Use. 2006. Disponível em: https://www.ipcc-nggip.iges.or.jp/public/2006gl/ Acesso em: 03 fev. 2019.

MAACK, Reinhard. Geografia Física do estado do Paraná.2 ed. Rio de Janeiro: José Olympio; Curitiba: Secretaria da Cultura e do Esporte do Estado do Paraná, 1981.

MAPBIOMAS. Mapeamento de uso e cobertura da terra - Coleção 3.1. Disponível em: http://mapbiomas.org/ Acesso em: 03 mar. 2019.

MATTAR, E. P. L. et al. Federal Conservation Units in Brazil: The Situation of Biomes and Regions. Floresta e Ambiente, v. 25, n. 2, 2018.

MMA. Ministério do Meio Ambiente. Disponível em <http://mapas.mma.gov.br/mapas/aplic/probio/datadownload.htm?/pampa/dados/shape_file> Acesso em: 19 jul. 2018.

SOARES-FILHO, B. et al. Role of Brazilian Amazon protected areas in climate change mitigation. Proceedings of the National Academy of Sciences, v. 107, n. 24, p. 10821-10826, 2010.

OGLE, S. M. et al. Delineating managed land for reporting national greenhouse gas emissions and removals to the United Nations framework convention on climate change. Carbon Balance and Management, v. 13, n. 1, 2018.

RICARDO, F. Terras Indígenas \& Unidades de Conservação da natureza: o desafio das sobreposições. Organização Fany Ricardo. São Paulo: Instituto Socioambiental, 2004. 